\title{
HUBUNGAN DUKUNGAN KELUARGA DAN SIKAP IBU DENGAN \\ PELAKSANAAN PERAWATAN METODE KANGURU PADA BAYI BERAT LAHIR RENDAH DI RUANG PERINATOLOGI RSUD H. ABDUL MANAP KOTA JAMBI TAHUN 2016
}

\author{
Lidya $^{1}$
}

\begin{abstract}
The prevalence of low birth weight babies have estimated $15 \%$ of the entire world with the presence of limitations 3.3\%-38\%. BBLR has experiences great potential to health problems as a result of incomplete maturation and function of organs and body, RSUD H. Abdul Manap have two hundred thirty babies. There are fifty five (55) babies have born with low birth weight. 3 million infant deaths with lower weight $(L B W)$ can be prevented with the use of appropriate interventions to the treatment to wards kangaroos. This research is quantitative research to determine the relationship of family support and attitude to the implementation of kangoroo method for low birth weight babies in perinatology at a public hospital of H. Abdul Manap Jambi 2016. The samples were 55 people by using a total of sampling. Data was collected using a questionnaire that was distributed door to door univariate and bivariate analysis with chi square test. The results of research, there are women who had a baby of low birth weight. There are 39 people (70,0\%) don't care kangaroo method. Some people didn't get the support of family, it's about 33 person (60\%) and she think negative about that 31 people $(56,4 \%)$. It's hoped, the health workers in order to improve the health promotion of the implementation of the treatment of kangaroos in particular the impact of not making profit performance treatment method kangaroo.
\end{abstract}

Keywords: Implementation of kangaroo care method, support of family, attitude

\section{PENDAHULUAN}

World Health Organization (WHO) pada tahun 1961 menyatakan bahwa semua bayi baru lahir yang berat badannya kurang atau sama dengan 2500 gram disebut low birth weight infant (bayi berat lahir rendah/ BBLR), karena morbiditas dan mortalitas neonatus tidak hanya bergantung pada berat badannya tetapi juga pada tingkat kematangan (maturitas) bayi tersebut (Pantiawati, 2010).

Angka kejadian di Indonesia sangat bervariasi antara satu daerah dengan daerah lain, yaitu berkisar antara 9\%-30\%, hasil studi di 7 daerah multicenter diperoleh angka BBLR dengan rentang 2,1\%-17,2\% (Pantiawati, 2010). Survei

${ }^{1}$ Universitas Adiwangsa
Demografi Kesehatan Indonesia (SDKI) 2012 menunjukkan bahwa kematian neonatal tidak menurun dan berada diangka 19 kematian per 1000 kelahiran hidup.

Kematian postnatal sementara hanya turun dari sebelumnya 15 ditahun 2007 ke angka 13 per 1000 kelahiran hidup saat ini. Rata-rata kematian bayi di Indonesia masih cukup besar, berdasarkan survei Kesehatan dasar Departemen Kesehatan (2010) neonatus merupakan penyumbangan kematian terbesar pada tingginya kematian bayi dan dalam rentang tahun 20112012 angka neonatus tidak pernah mengalami penurunan. Hasil survei menunjukkan kejadian angka kematian bayi di Singapura yaitu 5 per 1000 kelahiran hidup dan di 
Malaysia angka kematian bayi telah mencapai 10 per 1000 kelahiran hidup, sedangkan di Indonesia angka kematian bayi paling tinggi.

Prevalensi bayi berat lahir rendah (BBLR) diperkirakan 15\% dari seluruh kelahiran didunia dengan batasan 3,3\%-38\% dan lebih sering terjadi dinegara-negara berkembang atau sosio-ekonomi rendah (Pantiawati, 2010). Riskesdas (2007) dalam Maryunani (2013) menjelaskan bahwa penyebab kematian bayi baru lahir 0-6 hari di Indonesia adalah prematuritas dan bayi berat lahir rendah $34 \%$ dan penyebab kematian bayi baru lahir usia 7-28 hari di Indonesia adalah prematuritas dan bayi berat lahir rendah $14 \%$.

Berdasarkan Riskesdas tahun 2013, jika diamati dari bayi lahir, prevalensi bayi dengan berat badan lahir rendah (BBLR) menurun dari $11,1 \%$ tahun 2010 menjadi $10,2 \%$ tahun 2013. Variasi antar propinsi sangat mencolok dari terendah di Sumatera Utara $(7,2 \%)$ sampai yang tertinggi di Sulawesi Tengah $(16,9 \%)$. Informasi tentang berat badan lahir dan panjang badan lahir anak balita didasarkan kepada dokumen/ catatan yang dimiliki oleh anggota RT (buku KIA, KMS, atau buku catatan kesehatan anak lainnya). Sebanyak $52,6 \%$ balita dengan catatan berat badan lahir dan $45 \%$ balita dengan catatan panjang badan lahir. Persentase bayi dengan panjang badan lahir pendek $(<48 \mathrm{~cm})$ cukup tinggi, yaitu sebesar 20,2\%. Jika dikombinasikan antara BBLR dan panjang badan lahir pendek, maka didapatkan di Indonesia sebanyak $4,3 \%$ balita yang BBLR dan juga memiliki panjang badan lahir pendek dan prevalensi tertinggi di Papua $(7,6 \%)$, terendah di Maluku
$(0,8 \%)$ dan untuk daerah Jambi $(3,8 \%)$.

Bayi berat lahir rendah (BBLR) ialah bayi baru lahir yang berat badannya saat lahir kurang dari 2.500 gram (sampai dengan 2.499 gram) (Prawirohardjo, 2008).

Bayi Berat Badan Lahir Rendah (BBLR) ialah bayi baru lahir dengan berat badan kurang atau sama dengan 2.500 gram, sedangkan bayi dengan berat badan kurang dari 1.500 gram termasuk dengan berat badan lahir sangat rendah (Pantiawati, 2010).

Bayi BBLR berpotensi besar untuk mengalami berbagai masalah kesehatan sebagai akibat belum lengkap dan matangnya organ dan fungsi tubuh. Masalah kesehatan yang perlu mendapat perhatian dari tim pelayanan kesehatan pada saat merawat bayi BBLR adalah masalah yang terjadi sebagai akibat belum sempurnanya pengaturan suhu tubuh, fungsi pernafasan, fungsi persyarafan, fungsi kardiovaskuler, sistem perdarahan, sistem pencernaan, sistem perkemihan dan sistem kekebalan tubuh (Maryunani, 2013)

BBLR biasanya memerlukan perawatan yang sangat istimewa dimana memerlukan inkubator dan dalam pengawasan yang sangat istimewa dimana memerlukan inkubator dan dalam pengawasan ketat di ruang Neonatal Intensive Care Unit (NICU). Bayi berat lahir rendah dengan tubuh yang kecil sangat sensitif terhadap perubahan suhu, oleh karena itulah bayi perlu dimasukkan kedalam inkubator yang telah diatur kestabilan suhunya (Proverawati, 2010).

Bayi berat lahir rendah sering terjadinya hipotermia karena hanya sedikitnya lemak tubuh dan sistem pengaturan suhu tubuh pada bayi 
baru lahir belum matang (Proverawati, 2010). Produksi panas yang berkurang oleh karena lemak coklat (brown fat) yag belum cukup atau kurangnya lemak coklat sehingga pengaturan suhu yang belum berfungsi sebagaimana mestinya (Maryunani, 2013).

Proverawati

mengatakan bayi berat lahir rendah (BBLR) sangat mudah mendapatkan infeksi, terutama infeksi nosokomial. Hasil penelitian Hodgman, Barton, Pavlova dan Fasset (2003) menunjukkan bahwa infeksi adalah penyebab utama kematian pada bayi berat lahir rendah.

Bayi dengan berat lahir rendah tidak semuanya mendapatkan pelayanan kesehatan dengan teknologi maju karena hambatan biaya, geografis, transportasi dan komunikasi. Pengganti inkubator diperlukan cara alternatif yang efektif dan ekonomis (WHO, 2003).

Bayi prematur akan cepat mengalami kehilangan panas badan dan menjadi hipotermia, karena pusat pengaturan panas badan belum berfungsi dengan baik, metabolisme rendah dan permukaan badan relatif luas. Oleh karena itu, bayi harus dirawat didalam inkubator. bila belum memiliki inkubator, bayi dapat menggunakan metode kanguru yaitu perawatan bayi baru lahir seperti bayi kanguru dalam kantung ibunya (Proverawati, 2010).

Nurlaila, dkk (2015) dalam penelitiannya menyatakan bahwa Ada hubungan pelaksanaan PMK dengan kejadian hipotermi pada Bayi Berat Lahir Rendah (BBLR) di Rumah Sakit Umum Kanujoso Djati wibowo Balik papan Tahun 2012.

Perawatan metode kanguru merupakan suatu cara khusus dalam merawat bayi berat lahir rendah. Perawatan ini dengan cara melakukan kontak langsung antara kulit bayi dengan kulit ibu. Kontak langsung ini berguna untuk membantu perkembangan kesehatan bayi melalui peningkatan kontrol suhu, menyusui, pencegahan infeksi dan kontak ibu dengan bayi yang dimulai ditempat perawatan diteruskan dirumah, dikombinasi dengan pemberian air susu ibu yang bertujuan agar bayi tetap hangat. Perawatan metode kanguru ini belum dapat dilaksanakan secara optimal (Departemen Kesehatan RI 2008).

Proverawati

(2010)

menyatakan bahwa perawatan metode kanguru (PMK) adalah perawatan bayi baru lahir dengan melekatkan bayi didada ibu (kontak kulit bayi dan kulit ibu) sehingga suhu tubuh bayi tetap hangat.

Setiawan (2010), Umumnya berat bayi naik 30 gram/hari, dengan perawatan metode kangguru bisa naik sampai 50 gram/hari. Karena makanan yang masuk tidak dipakai untuk menghangatkan tubuhnya dan bisa dipakai untuk menaikkan berat badan.

Perawatan metode kanguru (PMK) merupakan teknologi tepat guna sebagai pengganti inkubator, tetapi harus tetap dilakukan pemantauan oleh tenaga kesehatan sampai BBLR mencapai berat $\geq 2500$ gram. Perawatan metode kangguru (PMK) terbukti dapat menurunkan kejadian infeksi, penyakit berat, masalah menyusui dan ketidak puasan ibu serta meningkatkan hubungan antara ibu dengan bayi (Maryunani, 2013).

Hasil penelitian Tri Budi Lestari, dkk (2013) menyatakan bahwa dari 15 responden sikap ibu terhadap pelaksanaan perawatan metode kanguru di ruang bayi RSUD Dr. Soetomo Surabaya, menunjukkan bahwa sebagian besar responden 
memiliki sikap negatif sebanyak $53,33 \%$ dan yang memiliki sikap positif sebanyak 46,67\%.

Hasil penelitian Tri Budi Lestari, dkk (2013) menyatakan bahwa hubungan dukungan keluarga terhadap pelaksanaan perawatan metode kanguru responden yang mendapat dukungan keluarga sebanyak $60 \%$ dan yang tidak mendapat dukungan keluarga sebanyak $40 \%$.

RSUD H. Abdul Manap Kota Jambi merupakan salah satu Rumah Sakit milik pemerintah kota Jambi yang berbentuk rumah sakit umum (RSU). Rumah sakit ini juga merupakan pelayanan rujukan dari puskesmas di Kota Jambi.

Berdasarkan data pada Rumah Sakit Umum Daerah H. Abdul Manap Kota Jambi pada bulan Januari sampai Mei 2016 diketahui jumlah bayi lahir yaitu 230 orang. Adapun jumlah bayi berat lahir rendah (BBLR) yaitu 55 orang atau $24 \%$. Sedangkan jumlah bayi yang mendapat perawatan metode kangguru yaitu 30 orang atau $55 \%$ dan bayi mendapatkan rujukkan kembali ke rumah sakit Abdul Manap sejumlah 19 orang atau $35 \%$ dan kematian pada bayi berat lahir rendah dari bulan januari sampai mei sebanyak 3 orang atau 5,4\%. Pada rumah sakit mayang medical center (MMC) Jambi data bayi berat lahir rendah dari bulan Januari sampai Juli sebanyak 30 orang.

Berdasarkan survei awal di Rumah Sakit Umum Daerah $\mathrm{H}$. Abdul Manap Jambi pada bulan Juni 2016, diketahui dari 5 orang ibu yang memiliki bayi BBLR dan telah diajarkan pelaksanaan metode kanguru oleh petugas kesehatan di ruang perinatologi ketahui ada 3 orang bayi yang tidak melaksanakan perawatan metode kanguru dikarenakan sibuk bekerja ini menunjukkan kurangnya dukungan keluarga terhadap ibu bayi dalam menghadapi bayi berat lahir rendah dan ada pula yang merasa takut melaksanakan perawatan metode kanguru dirumah sehingga bayinya masuk kembali keruang perinatologi dengan keluhan tidak mau menyusui dikarenakan bayinya hipotermi sehingga tidak mengalami peningkatan berat badan, sehingga sikap ibu dalam menghadapi bayi berat lahir rendah masih kurang.

Berdasarkan latar belakang di atas, penulis tertarik untuk melakukan sebuah penelitian ilmiah berupa skripsi yang berjudul "Hubungan Dukungan Keluarga dan Sikap Ibu dengan Pelaksanaan Perawatan Metode Kangguru di Ruang Perinatologi Rumah Sakit Umum Daerah H. Abdul Manap Kota Jambi ".

\section{METODE PENELITIAN}

Penelitian ini merupakan penelitian yang menguji hubungan dukungan keluarga dan sikap ibu sebagai variabel independen dengan perawatan metode kangguru sebagai variabel dependen. Penelitian ini merupakan penelitian survey untuk membuktikan hipotesis yang telah disusun terhadap variabel-variabel yang akan diteliti di ruang perinatologi Rumah Sakit Daerah H. Abdul Manap Jambi Tahun 2016. Adapun populasi dalam penelitian ini adalah ibu bayi baru lahir dengan berat badan lahir rendah di ruang perinatologi RSUD H. Abdul Manap Jambi Tahun 2016 yang berjumlah 55 orang. Penentuan jumlah sampel menggunakan teknik total sampling yaitu semua populasi dapat dijadikan sampel yang berjumlah 55 orang.

Pada saat penelitian dari 55 responden hanya 48 responden yang 
memenuhi kriteria dan 7 responden dikeluarkan dari sampel. Oleh karena itu peneliti menggunakan data tambahan bayi berat lahir rendah dari ruang Perinatologi RSUD H. Abdul Manap Kota Jambi pada bulan Juni dan Juli 2016.

Penelitian ini dilakukan pada bulan Agustus 2016 di Ruang Perinatologi Rumah Sakit Umum Daerah H. Abdul Manap Kota Jambi secara door to door. (Sugiyono, 2008).

\section{HASIL DAN PEMBAHASAN}

Pelaksanaan perawatan metode kanguru dikelompokkan menjadi 2 kategori yaitu "Melakukan" jika ibu melakukan pelaksanaan perawatan metode kanguru dan "Tidak Melakukan" jika ibu tidak melakukan pelaksanaan perawatan metode kanguru.

Tabel 1. Distribusi Frekuensi Responden Berdasarkan Pelaksaan Perawatan Metode Kanguru di Ruang Perinatologi RSUD H. Abdul Manap Jambi Tahun 2016

\begin{tabular}{lcc}
\hline $\begin{array}{c}\text { Pelaksanaan Perawatan } \\
\text { Metode Kanguru }\end{array}$ & Frekuensi & Presentase \\
\hline Melakukan & 16 & $70,9 \%$ \\
Tidak Melakukan & 39 & $29,1 \%$ \\
\hline \multicolumn{1}{c}{ Jumlah } & 55 & $100 \%$ \\
\hline
\end{tabular}

Pelaksanaan perawatan metode kanguru merupakan salah satu hal terpenting bagi bayi berat lahir rendah untuk mempertahankan suhu tubuh bayi serta agar dapat menambah peningkatan berat badan bayi. Pada penelitian ini, pelaksanaan perawatan metode kanguru dikelompokkan pada 2 kelompok yaitu melakukan perawatan metode kanguru dan tidak melakukan perawatan metode kanguru. Didapatkan jumlah ibu yang melakukan pelaksanaan perawatan metode kanguru pada bayi berat lahir rendah sebanyak 16 orang $(29,1 \%)$ lebih sedikit dari ibu yang tidak melakukan pelaksanaan perawatan metode kanguru yaitu sebanyak 39 orang $(70,9 \%)$ di ruang Perinatologi RSUD H. Abdul Manap Jambi Tahun 2016.

Menurut Proverawati, (2010) Perawatan Metode Kanguru (PMK) adalah cara yang sederhana untuk merawat bayi baru lahir dengan meletakkan bayi didada ibu (kontak kulit bayi dan kulit ibu) sehingga bayi tetap hangat. Perawatan metode ini sangat menguntungkan terutama untuk bayi berat lahir rendah.

Hasil penelitian Tri Budi Lestari, dkk (2013) menyatakan bahwa pelaksaan perawatan metode kanguru dengan jumlah responden sebanyak 15 orang didapatkan hasil ibu yang melakukan perawatan metode kanguru dengan baik sebanyak 53,3\% dan yang melakukan dengan cukup sebanyak 46,67\%. Fasilitas dan pelayanan kesehatan yang diberikan dapat mempengaruhi pelaksaan perawatan metode kanguru, maka perlu diadakannya konseling dan penyuluhan kesehatan lebih pada upaya mengubah perilaku sasaran agar berperilaku sehat terutama pada aspek kognitif, sehingga sasaran penyuluhan telah sesuai dengan yang diharapkan.

Pada ibu yang memiliki bayi berat lahir rendah lebih banyak ibu tidak melakukan pelaksanaan perawatan metode kanguru dikarenakan ibu beranggapan bayi 
akan tetap hangat apabila cukup di berikan pakaian yang lengkap serta selimut dan berat badan bayi akan meningkat dengan diberikan susu yang lebih saja tanpa harus dilakukan pelaksanaan perawatan metode kanguru ini dikarenakan masih adanya ibu yang sibuk bekerja sehingga ibu tidak memiliki waktu untuk melakukan pelaksanaan perawatan metode kanguru sedangkan ibu yang melakukan pelaksanaan perawatan metode kanguru menginginkan hasil yang optimal terhadap bayinya agar bayi tetap terjaga kehangatannya serta dapat cepat meningkat berat badan bayi, adapun suami serta keluarga yang ikut membantu dalam pelaksanaan perawatan metode kanguru sehingga perawatan metode kanguru tetap terlaksanakan.

Dukungan keluarga responden dikelompokkan menjadi dua kategori, yaitu mendukung dan tidak mendukung

Tabel 2. Distribusi Frekuensi Responden Berdasarkan Dukungan Keluarga di Ruang Perinatologi RSUD H. Abdul Manap Kota Jambi Tahun 2016

\begin{tabular}{ccc}
\hline Dukungan Keluarga & Frekuensi & Presentase \\
\hline Tidak Mendukung & 33 & $60 \%$ \\
Mendukung & 22 & $40 \%$ \\
\hline Jumlah & 55 & $100 \%$ \\
\hline
\end{tabular}

Pada penelitian ini dukungan keluarga dikelompokkan menjadi 2 ketegori, yaitu mendukung bila responden menjawab > median, dan tidak mendukung bila responden menjawab benar $\leq$ median.

Hasil analisis univariat menunjukkan bahwa dukungan keluarga yang tidak mendukung lebih banyak sebanyak 33 orang $(60 \%)$ dari pada ibu yang mendapat dukungan keluarga sebanyak 22 orang (40\%).

Ibu yang tidak mendapat dukungan keluarga lebih banyak dari pada ibu yang mendapat dukungan keluarga dikarenakan masih acuh tak acuhnya suami dan keluarga lain terhadap perkembangan anak, serta beranggapan bahwa hanya ibu yang mengurus anak dan suami mencari nafkah sehingga pelaksanaan perawatan metode kanguru hanya dilakukan apabila ibu. Serta banyak ibu yang hanya tinggal bersama keluarga inti tanpa didampingi oleh anggota keluarga yang lain seperti orang tua ataupun saudara ibu itu sendiri.
Pada ibu yang memiliki bayi berat lahir rendah yang tidak mendapat dukungan keluarga dikarenakan suami sibuk mencari nafkah dan ibu yang mengurus bayinya ini terlihat dari ibu yang menjawab pernyataan bahwa ibu sering mendengar suami mengeluh pada saat melaksanakan perawatan metode kanguru yang menjawab sering sebanyak 26 orang $(47,3 \%)$ dan ibu yang menjawab tidak pernah sebanyak 9 orang $(16,4 \%)$ dan suami serta keluarga jarang mendampingi ibu pada saat ibu melaksanakan perawatan metode kanguru dengan ibu yang menjawab pernyataan sering sebanyak 26 orang $(47,3 \%)$ dan ibu yang menjawab tidak pernah 8 orang $(14,5 \%)$. Sedangkan ibu yang mendapat dukungan keluarga diberikan motivasi oleh keluarga bahwa ibu mampu merawat bayi berat lahir rendah dengan pelaksanaan perawatan metode kanguru sehingga suami dan keluarga membantu mencarikan informasi tentang pelaksanaan perawatan metode kanguru melalui 
buku atau yang lainnya ibu yang menjawab sering sebanyak 13 orang $(23,6 \%)$ dan ibu yang menjawab tidak pernah sebanyak 8 orang (14,5\%).

Dari hasil penelitian diatas dukungan keluarga terhadap ibu yang memiliki bayi berat lahir rendah masih kurang, sebaiknya sebagai suami dan keluarga agar dapat memotivasi dan mendukung ibu dalam merawat bayi berat lahir rendah dengan perawatan khusus seperti pelaksanaan perawatan metode kanguru agar ibu dapat semangat dalam merawat anaknya sehingga perkembangan bayi lebih cepat dan berat badan bayi lebih cepat meningkat.

$$
\text { Sikap responden }
$$

dikelompokkan menjadi 2 kategori yaitu positif dan negatif.

Tabel 3. Distribusi Frekuensi Responden Berdasarkan Sikap Ibu di Ruang Perinatologi RSUD H. Abdul Manap Kota Jambi Tahun 2016

\begin{tabular}{lccc}
\hline & Sikap & Frekuensi & Presentase \\
\hline Negatif & & 31 & $56,4 \%$ \\
Positif & & 24 & $43,6 \%$ \\
\hline & Jumlah & 55 & 100 \\
\hline
\end{tabular}

Pada penelitian ini sikap responden dikelompokkan menjadi 2 kategori, yaitu positif bila responden menjawab > media, dan negatif bila responden menjawab $\leq$ median.

Hasil analisis univariat menunjukkan bahwa ibu yang bersikap negatif lebih banyak yaitu 31 orang $(56,4 \%)$ dari pada ibu yang bersikap positif yaitu 24 orang $(43,6 \%)$.

Pada ibu yang memiliki bayi berat lahir rendah yang bersikap negatif lebih banyak dibandingkan ibu yang bersikap positif, karena masih adanya ibu yang menganggap bahwa bayi berat lahir rendah sama perawatannya dengan bayi dengan berat normal lainnya sehingga tidak ada diberikan perawatan secara khusus kepada bayi berat lahir rendah seperti tidak perlu memandikan bayi berat lahir rendah karena akan menyebabkan bayi hipotermi terlihat pada saat ibu menjawab pertanyaan yang bersikap setuju lebih banyak yaitu 23 orang $(41,8 \%)$ dibandingkan ibu yang menjawab tidak setuju yaitu 12 orang $(21,8 \%)$ dan ibu masih rendahnya keinginan ibu untuk merawatan bayi berat lahir rendah dengan perawatan khusus seperti pelaksanaan perawatan metode kanguru dirumah ini, ini terlihat dari ibu menjawab pernyataan ibu bersikap tidak setuju lebih tinggi yaitu 25 orang $(45,5 \%)$ dibandingkan ibu yang bersikap sangat setuju yaitu 9 orang $(16,4 \%)$. Ibu yang bersikap positif menganggap bahwa pelaksanaan perawatan metode kanguru tidak hanya bisa dilakukan oleh ibu saja tetapi juga dapat dilakukan oleh anggota keluarga yang lain, ini terlihat dari ibu menjawab pernyataan, ibu yang bersikap setuju sebanyak 25 orang $(45,5 \%)$ dan ibu yang menjawab sangat tidak setuju sebanyak 5 orang $(9,1 \%)$.

Dari hasil penelitian diatas sikap ibu yang memiliki bayi berat lahir rendah terhadap pelaksanaan perawatan metode kanguru masih kurang baik, maka sebaiknya ibu yang memiliki bayi berat lahir rendah meningkatkan keingin tahuan terhadap cara perawatan bayi berat lahir rendah khususnya dalam pelaksanaan perawatan metode kanguru dengan cara membawa bayi ke pusat pelayanan kesehatan agar 
dikontrol pertumbuhan berat badannya serta banyak membaca buku tentang perawatan bayi berat lahir rendah agar dapat merawat bayi berat lahir rendah dengan perawatan khusus salah satunya pelaksanaan perawatan metode kanguru secara optimal.

\section{Hubungan Dukungan Keluarga dengan Pelaksanaan Perawatan Metode Kanguru di Ruang}

Perinatologi RSUD H. Abdul Manap Kota Jambi Tahun 2016.

Penelitian ini dilakukan pada 55 responden dimana dukungan keluarga dibagi menjadi dua yaitu mendukung dan tidak mendukung sedangkan pelaksanaan perawatan metode kanguru dibagi menjadi 2 kategori yaitu melakukan pelaksanaan perawatan metode kanguru dan tidak melakukan pelaksanaan perawatan metode kanguru.

Tabel 4. Hubungan Antara Dukungan Keluarga dengan Pelaksanaan Perawatan Metode Kanguru di Ruang Perinatologi RSUD H. Abdul Manap Kota Jambi Tahun 2016.

\begin{tabular}{lccccccc}
\hline \multirow{2}{*}{$\begin{array}{c}\text { Dukungan } \\
\text { Keluarga }\end{array}$} & \multicolumn{9}{c}{ Pelaksanaan Perawatan Metode } & \multicolumn{2}{c}{ Jumlah } & \multirow{2}{*}{ Kanguru Value } \\
\cline { 2 - 7 } & \multicolumn{9}{c}{ Tidak Melakukan } & Melakukan & N & \% & \\
\hline Mendukung & 9 & $40,9 \%$ & 13 & $59,1 \%$ & 22 & $40 \%$ & 0,000 \\
Tidak Mendukung & 30 & $90,9 \%$ & 3 & $9,1 \%$ & 33 & $60 \%$ & \\
\cline { 1 - 7 } Jumlah & 39 & $70,9 \%$ & 16 & $29,1 \%$ & 55 & 100 & \\
\hline
\end{tabular}

Pada penelitian ini dilakukan di Ruang Perinatologi RSUD H. Abdul Manap Kota Jambi Tahun 2016 dengan jumlah sampel 55 responden diperolah hasil dari 22 responden yang mendapat dukungan keluarga 9 orang $(40,9 \%)$ tidak melakukan pelaksaan perawatan metode kanguru sedangkan 13 orang melakukan pelaksanaan perawatan metode kanguru dan dari 33 responden yang tidak mendapat dukungan keluarga sebanyak 30 orang $(90,9 \%)$ tidak melakukan pelaksanaan perawatan metode kanguru sedangkan 3 orang $(9,1 \%)$ melakukan pelaksanaan perawatan metode kanguru.

Berdasarkan hasil uji Chisquare didapatkan $P$ value lebih kecil dari $\alpha(0,05)$ yaitu 0,000 . hasil ini menunjukkan bahwa ada hubungan yang bermakna antara dukungan keluarga dengan pelaksanaan perawatan metode kanguru pada bayi berat lahir rendah di Ruang Perinatologi RSUD $\mathrm{H}$.
Abdul Manap Kota Jambi Tahun 2016.

Teori Straight (2001) dalam PERINASIA (2010) mengatakan bahwa, keluarga memegang peranan penting dalam asuhan bayi baru lahir. Keluarga mempunyai potensi untuk menentukan asuhan yang terbaik untuk bayinya berdasarkan informasi yang akurat dari tenaga kesehatan. Oleh sebab itu pelibatan keluarga harus menjadi bagian dari asuhan bayi baru lahir. Tujuan asuhan yang berpusat pada keluarga adalah memberikan rasa aman, meningkatkan kemampuan orang tua dalam merawat diri dan bayinya, mempromosikan kesejahteraan ibu dan bayi dengan memperhatikan keyakinan, nilai, tradisi, budaya yang dianut keluarga.

Berdasarkan hasil penelitian Tri Budi Lestari, dkk (2013) dengan jumlah responden sebanyak 15 orang terdapat pelaksanaan perawatan metode kanguru yang baik terbanyak 
pada responden dengan dukungan keluarga yang baik yaitu sebanyak 9 orang (60\%). Dukungan keluarga yang baik yang mempengaruhi pelaksanaan perawatan metode kanguru adalah keluarga selalu memberi motivasi pada ibu untuk melakukan perawatan metode kanguru, memperhatikan kondisi kesehatan ibu agar dapat melakukan perawatan metode kanguru dan merasa senang dengan perkembangan bayinya yang semakin baik. Sebagian yang lain terdapat 6 responden $(40 \%)$ dengan dukungan keluarga yang cukup dengan pelaksanaan perawatan metode kanguru yang cukup. Dukungan keluarga yang cukup kepada responden yang mempengaruhi pelaksanaan perawatan metode kanguru yang cukup adalah keluarga kurang memberi motivasi pada ibu untuk melakukan perawatan metode kanguru, tidak selalu mendampingi ibu saat berkonsultasi dengan petugas kesehatan, dan kurang aktif mencari informasi terkait dengan pelaksanaan perawatan metode kanguru.

Berdasarkan hasil penelitian di Ruang Perinatologi RSUD H. Abdul Manap Kota Jambi Tahun 2016 responden yang tidak mendapat dukungan keluarga terhadap pelaksanaan perawatan metode kanguru masih banyaknya suami serta keluarga ibu yang mengganggap acuh tak acuh terhadap perawatan bayi berat lahir rendah serta kurang mengetahuinya keuntungan dari pelaksanaan perawatan metode kanguru karena suami dan keluarga menganggap perawatan bayi berat lahir rendah sama dengan perawatan bayi normal biasanya. Sedangkan ibu yang mendapat dukungan keluarga sebagian besar melakukan pelaksanaan perawatan metode kanguru karena menginginkan perawatan yang optimal kepada bayi berat lahir rendah agar berat badan bayi cepat meningkat serta agar bayi tidak kedingingan dengan melakukan kontak kulit ibu dengan kulit bayi.

Pada tabel 4 ibu yang mendapat dukungan keluarga masih ada yang tidak melakukan pelaksanaan perawatan metode kanguru disebabkan karena tingkat pendidikan yang rendah sehingga mempengaruhi tingkat pengetahuan ibu, tetapi masih adanya ibu yang memiliki pendidikan tinggi (perguruan tinggi) tidak menunjukkan respon yang baik terhadap pelaksaan perawatan metode kanguru karena ibu terlalu sibuk untuk bekerja sehingga kurang memperhatikan perkembangan anaknya, usia yang masih muda sehingga masih belum memiliki banyak pengalaman dan kurangnya mencari informasi tentang bayi berat lahir rendah khususnya pelaksanaan perawatan metode kanguru. Sedangkan ibu yang tidak mendapat dukungan keluarga tetapi mau melakukan pelaksaan perawatan metode kanguru disebabkan keingin tahuan ibu dalam mencari informasi tentang pelaksaan perawatan metode kanguru pada buku, dan bertanya kepada orang lain yang lebih paham.

Untuk itu rumah sakit dapat memberikan penyuluhan kepada ibu yang memiliki bayi berat lahir rendah khususnya mengenai keuntungan dari pada pelaksanaan perawatan metode kanguru bukan hanya kepada ibu bayi saja tetapi juga kepada suami dan anggota keluarga yang lain agar suami serta anggota keluarga yang lain dapat mengetahui serta mau melakukan pelaksanaan perawatan metode 
kanguru dirumah agar berat badan bayi lebih cepat meningkat dan tidak terjadi komplikasi lain terhadap bayi selama perawatan bayi di rumah. Selain itu sebaiknya pihak rumah sakit memberikan leaflet - leaflet tentang pelaksanaan perawatan metode kanguru kepada ibu yang memiliki bayi berat lahir rendah pada saat penyuluhan ataupun pada saat ibu melakukan kontrol ulang untuk membantu ibu dan keluarga dalam melaksanakan perawatan metode kanguru dirumah.

Tabel 5. Hubungan Antara Sikap Ibu dengan Pelaksanaan Perawatan Metode Kanguru di Ruang Perinatologi RSUD H. Abdul Manap Kota Jambi Tahun 2016.

\begin{tabular}{|c|c|c|c|c|c|c|c|}
\hline \multirow[t]{2}{*}{ Sikap } & \multicolumn{4}{|c|}{$\begin{array}{c}\text { Pelaksanaan Perawatan Metode } \\
\text { Kanguru }\end{array}$} & \multicolumn{2}{|c|}{ Jumlah } & \multirow[t]{2}{*}{ P Value } \\
\hline & \multicolumn{2}{|c|}{$\begin{array}{c}\text { Tidak } \\
\text { Melakukan }\end{array}$} & \multicolumn{2}{|c|}{ Melakukan } & $\mathbf{N}$ & $\%$ & \\
\hline Negatif & 29 & $93,5 \%$ & 2 & $6,5 \%$ & 31 & $56,4 \%$ & 0,000 \\
\hline Positif & 10 & $41,7 \%$ & 14 & $58,3 \%$ & 24 & $43,6 \%$ & Ada Hubungan \\
\hline Jumlah & 39 & $70,9 \%$ & 16 & $29,1 \%$ & 55 & 100 & \\
\hline
\end{tabular}

Pada penelitian yang dilakukan di Ruang Perinatologi RSUD $\mathrm{H}$. Abdul Manap Kota Jambi Tahun 2016 diperoleh hasil dari 31 ibu yang bersikap negatif sebanyak 29 orang $(93,5 \%)$ tidak melakukan pelaksanaan perawatan metode kanguru dan sebanyak 2 orang $(6,5 \%)$ melakukan pelaksanaan perawatan metode kanguru dan 24 orang yang bersikap positif sebanyak 10 orang $(41,7 \%)$ tidak melakukan pelaksanaan perawatan metode kanguru dan sebanyak 14 orang $(58,3 \%)$ melakukan pelaksanaan perawatan metode kanguru.

Berdasarkan hasil uji Chisquare didapatkan $P$ value lebih kecil dari $\alpha(0,05)$ yaitu 0,000 . Hasil ini menunjukkan bahwa ada hubungan yang bermakns antara sikap ibu dengan pelaksanaan perawatan metode kanguru di Ruang
Hubungan Sikap Ibu dengan Pelaksanaan Perawatan Metode Kanguru di Ruang Perinatologi RSUD H. Abdul Manap Kota Jambi Tahun 2016.

Penelitian ini dilakukan pada 55 responden dimana sikap ibu dibagi menjadi 2 kategori yaitu positif dan negatif. Sedangkan pelaksanaan perawatan metode kanguru dibagi menjadi 2 kategori yaitu melakukan dan tidak melakukan 
15 responden, sikap ibu terhadap pelaksanaan perawatan metode kanguru di ruang bayi RSUD Dr. Soetomo Surabaya, menunjukkan bahwa sebagian besar responden memiliki sikap negatif terhadap pelaksanaan perawatan metode kanguru yaitu sebanyak 8 orang $(53,33 \%)$. Sikap ibu yang negatif didukung oleh sikap ibu yang sangat tidak setuju bahwa saat melaksanakan perawatan metode kanguru dapat dilakukan sendiri apabila ibu sudah terbiasa melakukannya dan tidak setuju apabila melakukan perawatan metode kanguru dirumah dapat dilakukan sambil melakukan aktivitas ringan. Pada dasarnya ibu yang yang sudah terbiasa melakukan perawatan metode kanguru tidak perlu selalu dengan bantuan karena sudah terlahit. Sedangkan ibu yang bersikap positif terhadap pelaksanaan perawatan metode kanguru sebanyak 7 orang $(46,67 \%)$ yang didukung oleh sikap ibu yang sangat setuju bahwa perawatan metode kanguru sangat tepat untuk BBLR terutama dalam mempertahankan kehangatan tubuh bayi sebagai pengganti inkubator dan melaksanakan perawatan metode kanguru dapat memberikan kasih sayang secara langsung pada bayinya.

Berdasarkan hasil penelitian di Ruang Perinatologi RSUD H. Abdul Manap Kota Jambi Tahun 2016 bahwa ibu yang bersikap negatif lebih tinggi dari pada ibu yang bersikap positif karena masih kurangnya keingin tahuan ibu tentang bayi berat lahir rendah sehingga ibu menanggap bahwa perawatan bayi berat lahir rendah sama dengan perawatan bayi dengan berat normal sehingga tidak ada perawatan khusus untuk bayi dengan berat lahir rendah serta masih adanya ibu yang kurang bisa menerima memiliki anak dengan berat lahir rendah. Selain itu masih sibuknya ibu bekerja sehingga kurang memperhatikan perkembangan serta kebutuhan bayinya yang memerlukan perawatan khusus seperti pelaksanaan perawatan metode kanguru agar berat badan bayi lebih cepat meningkat serta mempertahankan kehangatan tubuh bayi. Oleh karena itu ibu masih beranggapan apabila bayi diberikan susu formula sertadiberikan selimut sudah cukup untuk merawat bayinya.

Pada tabel 5 menunjukkan bahwa ibu yang bersikap negatif masih ada yang mau melakukan pelaksanaan perawatan metode kanguru disebabkan oleh dorongan serta motivasi dari keluarga khususnya suami agar dapat memberikan perawatan yang optimal salah satunya dengan pelaksanaan perawatan metode kanguru. Sedangakan ibu yang bersikap positif ada juga yang tidak melakukan pelaksanaan perawatan metode kanguru dikarenakan masih rendahnya tingkat pendidikan karena tingkat pendidikan yang kurang mempengaruhi terhadap pengetahuan seseorang. Pengetahuan yang kurang dapat mempengaruhi terhadap pemahaman seseorang terhadap stimulus. Pemahaman yang kurang terhadap pengetahuan tentang pelaksanaan perawatan metode kanguru menyebabkan responden memiliki sikap yang negatif atau kurang mendukung. Selain itu masih banyaknya ibu yang sibuk bekerja, ibu yang menganggap bahwa pelaksanaan perawatan metode kanguru memang penting untuk peningkatan perkembangan anaknya tetapi karena tidak adanya waktu untuk merawat bayi secara optimal sehingga tidak melakukan 
pelaksanaan perawatan metode kanguru.

Untuk itu sebaiknya rumah sakit melakukan penyuluhan khususnya tentang cara perawatan khusus bagi bayi berat lahir rendah serta memberikan informasi tentang keuntungan dan dampak tidak dilakukannya pelaksaan perawatan metode kanguru pada bayi berat lahir rendah. Selain itu sebaiknya tenaga kesehatan di pusat pelayanan lainnya seperti rumah bersalin, puskesmas maupun rumah sakit melakukan penyuluhan kepada ibu-ibu yang memiliki bayi berat lahir rendah serta melakukan praktek langsung cara pelaksanaan perawatan metode kanguru kepada ibu-ibu yang memiliki bayi berat lahir rendah agar ibu lebih tertarik dan lebih paham dalam melakukan pelaksanaan perawatan metode kanguru terhadap anaknya. Selain itu sebaiknya pihak rumah sakit memberikan bukti nyata perbedaan bayi yang sduah dilakukan pelaksanaan perawatan metode kanguru dan yang tidak melakukan perawatan metode kanguru.

\section{SIMPULAN}

Dari hasil penelitian yang dilakukan di Ruang Perinatologi RSUD H. Abdul Manap Kota Jambi Tahun 2016 dapat disimpulkan Distribusi frekuensi ibu yang tidak melakukan pelaksanaan perawatan metode kanguru lebih banyak yaitu 39 responden $(70,9 \%)$ dibandingkan ibu yang melakukan pelaksanaan perawatan metode kanguru yaitu 16 orang $(29,1 \%)$; Distribusi frekuensi ibu yang tidak mendapat dukungan keluarga lebih banyak yaitu 33 responden $(60 \%)$ dari pada ibu yang mendapat dukungan keluarga yaitu 22 responden (40\%); Distribusi frekuensi ibu yang bersikap negatif lebih banyak yaitu 31 responden
$(56,4 \%)$ dibandingkan ibu yang bersikap positif yaitu 24 responden (43,6\%); Ada hubungan yang bermakna antara dukungan keluarga dengan pelaksanaan perawatan metode kanguru dengan tingkat kemaknaan $\alpha=0,05$ dimana $P$ value $=0,000$ lebih kecil dari $\alpha=0,05$ dan ada hubungan yang bermakna antara sikap ibu dengan pelaksanaan perawatan metode kanguru dengan tingkat kemaknaan $\alpha=0,05$ dimana $P$ value $=0,000$ lebih kecil dari $\alpha=$ 0,05 .

\section{DAFTAR PUSTAKA}

Depkes RI. 2008. Perawatan Bayi Berat Lahir Rendah (BBLR) Dengan Metode Kanguru. Departemen Kesehatan Republik Indonesia: Jakarta.

Maryunani. 2013. Buku Saku Asuhan Bayi Dengan Berat Badan Lahir Rendah. CV.Trans Info medika: Jakarta.

Notoatmodjo, Soekidjo. 2012. Promosi Kesehatan Dan Perilaku Kesehatan. PT.Rineka Cipta: Jakarta

Nurlaila, dkk. 2015. Hubungan Pelaksanaan Perawatan Metode Kanguru (PMK) Dengan Kejadian Hipotermia Pada Bayi Berat Lahir Rendah (BBLR). Vol.III. Diakses tanggal 02 Juli 2016.

Nursalam. 2013. Metodologi Penelitian Ilmu Keperawatan. Jakarta: Salemba Medika.

Pantiawati. 2010. Bayi Dengan BBLR (Berat Badan Lahir Rendah). Nuha Medika: Jakarta

PERINASIA. 2010. Konsep Dasar Perawatan Metode Kanguru, tulisan dipresentasikan pada Penelitian Perawatan Metode Kanguru. Surabaya, 15-19 Februari. 
Prawirohardjo, Sarwono. 2008. Ilmu

Kebidanan. Bina Pustaka:

Jakarta.

Proverawati dan Cahyo Ismawati.

2010. Berat Badan Lahir

Rendah, Nuha Medika:

Yogyakarta.

RISKESDAS. Laporan Hasil Riset

Kesehatan Dasar tahun 2013,

Kementrian Kesehatan RI:

Jakarta.

Setiawan, Ari, dkk. 2010. Metode

Penelitian Kebidanan. Nuha

Medika: Jakarta.

Sugiyono, 2008. Metode Penelitian

Kuntitatif Kualitatif dan $R \& D$.

Alfabeta: Bandung

Tri Budi Lestari, dkk. 2013.

http://www.FaktorPelaksanaan

KangorooMotherCarePadaBay

iBBLR. (Diakses 20 Juli 2016).

WHO. 2003. Kanguru Mother care:

A Practical Guide. Geneva:

WHO.

Hubungan Dukungan Keluarga Dan Sikap Ibu Dengan Pelaksanaan Perawatan Metode Kanguru Pada Bayi Berat Lahir Rendah Di Ruang Perinatologi RSUD H. Abdul Manap Kota Jambi Tahun 2016 